Article

\title{
Acyclic Triterpenoids from Alpinia katsumadai Inhibit IL-6-Induced STAT3 Activation
}

\author{
Hyun-Jae Jang, Seung-Jae Lee, Soyoung Lee, Kyungsook Jung, Seung Woong Lee * (DD and \\ Mun-Chual Rho * \\ Immunoregulatory Material Research Center, Korea Research Institute of Bioscience and Biotechnology, \\ 181 Ipsin-gil, Jeongeup-si, Jeonbuk 56212, Korea; water815@kribb.re.kr (H.-J.J.); seung99@kribb.re.kr (S.-J.L.); \\ sylee@kribb.re.kr (S.L.); jungks@kribb.re.kr (K.J.) \\ * Correspondence: lswdoc@kribb.re.kr (S.W.L.); rho-m@kribb.re.kr (M.-C.R.); Tel.: +82-63-570-5264 (S.W.L.); \\ +82-63-570-5230 (M.-C.R.); Fax: +82-63-570-5239 (S.W.L. \& M.-C.R)
}

Received: 25 August 2017; Accepted: 21 September 2017; Published: 25 September 2017

\begin{abstract}
The seeds of Alpinia katsumadai yielded two new acyclic triterpenoids, 2,3,6,22,23 -pentahydroxy -2,6,11,15,19,23-hexamethyl-tetracosa-7,10,14,18-tetraene (3) and 2,3,6,22,23 -pentahydroxy-2,10,15,19,23-hexamethyl-7-methylenetetracosa-10,14,18-triene (4), as well as two known compounds, 2,3,22,23-tertrahydroxy-2,6,10,15,19,23-hexamethyl-tetracosa-6,10,14,18-tetraene (1) and 2,3,5,22,23-pentahydroxy-2,6,10,15,19,23-hexamethyl-tetracosa-6,10,14,18-tetraene (2). The absolute configurations of 2 and 3, which were determined by means of a modified Mosher's method, are suggested as $(3 R ; 5 S ; 22 R)$ and $(3 R ; 22 R)$, respectively. Compounds $1-4$ inhibited IL-6-induced JAK2/STAT3 activity in a dose-dependent fashion, with $\mathrm{IC}_{50}$ values of $0.67,0.71,2.18$, and $2.99 \mu \mathrm{M}$. Moreover, IL-6-stimulated phosphorylation of STAT3 was significantly suppressed in U266 cells by the administration of A. katsumadai EtOH extract and Compounds 1 and 2. These results suggest that major phytochemicals, Compounds $\mathbf{1}$ and 2, obtained from A. katsumadai may be useful candidates for designing new IL-6 inhibitors as anti-inflammatory agents.
\end{abstract}

Keywords: Alpinia katsumadai; acyclic triterpenoids; IL-6; STAT3; inflammation

\section{Introduction}

Interleukin-6 (IL-6) is a pro-inflammatory cytokine that is secreted by immune and inflammatory-related cells ( $\mathrm{T}$ cells and macrophages) to stimulate responses to viral infection, trauma, and other tissue damage [1,2]. Several studies have demonstrated that overproduction of IL-6 is relevant to many human diseases, such as cancer cachexia [3], rheumatoid arthritis [4], atherosclerosis [5], diabetes [6], and multiple myeloma [7]. IL-6 also impairs the endothelium-dependent dilatation of human veins in vivo [8]. Therefore, IL-6 is implicated in the pathogenesis of immune and inflammatory diseases, and blocking IL-6 would be an effective treatment for many of these human diseases. The seeds of Alpinia katsumadai Hayata (Zingiberaceae) are widely utilized as a traditional Chinese herbal medicine to treat inflammatory and digestive diseases [9]. The seeds contain a variety of major constituents, including diarylheptanoids [10-12], monoterpenes [13,14], sesquiterpenoids [15], flavonoids [16], and chalcones [15]. Additionally, the extracts and compounds isolated from this plant exhibit various biological properties, including antiemetic [12], antiproliferative [17], antiviral [18,19], antiasthmatic [20], antiseptic [21], and cytoprotective effects [22]. We have searched for IL-6 inhibitors from natural sources, and the EtOH extract of the seeds of A. katsumadai (AKEE) exhibited potent inhibitory effects on IL-6-induced STAT3 (signal transducer and activator of transcription 3) activity (see Table S1 in Supplementary Materials). Herein, we report the isolation and structural elucidation of new acyclic triterpenoid derivatives (3 and 4), and describe the biological properties of Compounds 1-4. 


\section{Results and Discussion}

\subsection{Isolation of Compounds}

The EtOH extract was suspended in $\mathrm{H}_{2} \mathrm{O}$ and partitioned with $\mathrm{CHCl}_{3} \cdot \mathrm{CHCl}_{3}$-soluble materials, including active substances, were fractionated via open-column chromatography on silica gel and ODS (octadecylsilanized silica gel, $\mathrm{C}_{18}$ ) and subjected to semi-preparative HPLC to yield two known acyclic triterpenoids ( $\mathbf{1}$ and $\mathbf{2}$ ) and two new compounds (3 and $\mathbf{4}$ ).

\subsection{Determination of the Acyclic Triterpenoids Structure}

Compound 1 was obtained as a yellow oil with $[\alpha]_{\mathrm{D}}^{20}+18.1\left(\mathrm{CHCl}_{3}, c 1.0\right)$. It exhibited a sodium adduct ion peak at $m / z 501[\mathrm{M}+\mathrm{Na}]^{+}$in the ESIMS and a molecular formula of $\mathrm{C}_{30} \mathrm{H}_{54} \mathrm{O}_{4}$. The ${ }^{13} \mathrm{C}$-NMR spectrum of 1 contained 15 peaks, which was half the number predicted from the ESIMS spectral data. A symmetrical structure with 30 carbons was suggested. The ${ }^{1} \mathrm{H}-\mathrm{NMR}$ spectrum of 1 showed signals due to 10 methylene groups $\left(\delta_{\mathrm{H}} 1.40,1.58,1.99 \sim 2.08\right.$ and 2.23), four methyl groups $\left(\delta_{\mathrm{H}} 1.59\right.$ and 1.61), and four olefinic groups $\left(\delta_{\mathrm{H}} 5.13\right.$ and 5.18). Two methine groups $\left(\delta_{\mathrm{H}} 3.36, \mathrm{dd}\right.$, $J=10.5,2.0 \mathrm{~Hz})$ attached to hydroxy groups, and four terminal methyl groups $\left(\delta_{\mathrm{H}} 1.15\right.$ and 1.19$)$ were also observed. In addition, signals at $\delta_{C} 73.0$ and 78.2, attributed to oxygenated carbon, indicated the presence of a hydroxy group in the ${ }^{13} \mathrm{C}-\mathrm{NMR}$ spectrum of $\mathbf{1}$. The connectivity of proton and carbon atoms was assigned based on ${ }^{1} \mathrm{H},{ }^{13} \mathrm{C}$ and $\mathrm{HMQC}$ spectra. Therefore, the structure of $\mathbf{1}$ was identified as 2,3,22,23-tetrahydroxy-2,6,10,15,19,23-hexamethyl-tetracosa-6,10,14,18-tetraene by spectroscopic methods $\left({ }^{1} \mathrm{H}-,{ }^{13} \mathrm{C}-\mathrm{NMR}\right.$ and $\left.\mathrm{MS}\right)$ and by comparing the data with previously reported values (Figure 1) [23]. The absolute configuration was identified as $\mathbf{3 R}, \mathbf{2 2} \boldsymbol{R}$ by comparison of the optical rotation value and ${ }^{1} \mathrm{H}-\mathrm{NMR}$ spectra in previous reports [24].<smiles>[R]P[R]([Y])([H])O</smiles>

3<smiles>C=C(CC/C(C)=C/CC/C=C(\C)CC/C=C(\C)CC[C@H](O)C(C)(C)O)[C@H](O)CC[C@@H](O)C(C)(C)O</smiles>

Figure 1. Chemical structure of Compounds 1-4.

Compound 2 was isolated as a yellow oil with $[\alpha]_{\mathrm{D}}^{20}+4.8\left(\mathrm{CHCl}_{3}, c 1.0\right)$. It displayed a peak at $m / z$ 493.3897 in the spectrum obtained by high-resolution electrospray ionization mass spectrometry (HRESIMS) corresponding to $[\mathrm{M}-\mathrm{H}]^{-}$(calcd. 493.3893), indicating a molecular formula of $\mathrm{C}_{30} \mathrm{H}_{54} \mathrm{O}_{5}$. In the ${ }^{1} \mathrm{H}-\mathrm{NMR}$ spectrum of 2 (Table 1), four olefinic protons were observed at $\delta_{\mathrm{H}}$ $5.14(2 \mathrm{H}, \mathrm{m}, \mathrm{H}-11, \mathrm{H}-14), 5.19(1 \mathrm{H}, \mathrm{t}, J=6.4 \mathrm{~Hz}, \mathrm{H}-18)$, and $5.43(1 \mathrm{H}, \mathrm{t}, J=6.4 \mathrm{~Hz}, \mathrm{H}-7)$, which indicated that 2 has a more asymmetrical structure than 1 . In addition, six allylic methylene groups at $\delta_{\mathrm{H}} 1.41$, $1.59,2.02,2.05,2.10$, and 2.13 (each $\left.2 \mathrm{H}, \mathrm{m}, \mathrm{H}_{2}-12,13,16,9,17,8\right)$, four methyl groups at $\delta_{\mathrm{H}} 1.60,1.61$, 1.62 and 1.63 (each $\left.3 \mathrm{H}, \mathrm{s}, \mathrm{H}_{3}-29,28,27,26\right)$, and two methylene groups at $\delta_{\mathrm{H}} 2.09$ and 2.23 (each $2 \mathrm{H}$, $\mathrm{m}, \mathrm{H}_{2}-21$ and 20) were observed. A methylene group between two hydroxy groups was observed at 
$\delta_{\mathrm{H}} 1.63\left(2 \mathrm{H}, \mathrm{m}, \mathrm{H}_{2}-4\right)$. Additionally, the signals of three methine groups at $\delta_{\mathrm{H}} 3.35(1 \mathrm{H}, \mathrm{d}, J=10.4 \mathrm{~Hz}$, $\mathrm{H}-22), 3.62(1 \mathrm{H}, \mathrm{m}, \mathrm{H}-3)$, and $4.26(1 \mathrm{H}, \mathrm{dd}, J=7.6,4.8 \mathrm{~Hz}, \mathrm{H}-5)$ and four terminal methyl groups at $\delta_{\mathrm{H}} 1.15,1.17,1.19$, and 1.20 (each $3 \mathrm{H}, \mathrm{s}, \mathrm{H}_{3}-30,25,24,1$ ) were observed. The ${ }^{13} \mathrm{C}-\mathrm{NMR}$ spectrum of 2 (Table 1) revealed the presence of 30 carbons, and the connectivity of the proton and carbon atoms was elucidated via DEPT and HMQC analyses. In the ${ }^{13} \mathrm{C}-\mathrm{NMR}$ spectrum, the signals at $\delta_{\mathrm{C}} 78.5$, 78.6, and 78.9 were attributed to methine carbon and suggested the presence of three hydroxy groups. In the HMBC experiment (Figure 2), long-range couplings were observed from $\mathrm{H}-7\left(\delta_{\mathrm{H}} 5.43\right)$ to $\mathrm{C}-5$ $\left(\delta_{C} 78.6\right), C-9\left(\delta_{C} 39.4\right)$ and $C-26\left(\delta_{C} 11.9\right)$, from H-5 $\left(\delta_{H} 4.26\right)$ to $C-3\left(\delta_{C} 78.5\right), C-7\left(\delta_{C} 126.6\right)$ and C-26 $\left(\delta_{\mathrm{C}} 11.9\right)$, and from $\mathrm{H}-3\left(\delta_{\mathrm{H}} 3.62\right)$ to $\mathrm{C}-5\left(\delta_{\mathrm{C}} 78.6\right)$. The ${ }^{1} \mathrm{H}-{ }^{1} \mathrm{H}$ COSY spectrum of 2 showed correlated proton signals of $\mathrm{H}_{2}-4\left(\delta_{\mathrm{H}} 1.63\right)$ with $\mathrm{H}-3\left(\delta_{\mathrm{H}} 3.62\right)$ and $\mathrm{H}-5\left(\delta_{\mathrm{H}} 4.26\right)$. Therefore, we confirmed that the hydroxy group was attached at the $\mathrm{C}-5$ of 2 . We also observed long-range correlations from $\mathrm{H}-18\left(\delta_{\mathrm{H}} 5.43\right)$ to $\mathrm{C}-20\left(\delta_{\mathrm{C}} 37.0\right)$ and $\mathrm{C}-29\left(\delta_{\mathrm{C}} 16.2\right)$ and from $\mathrm{H}-22\left(\delta_{\mathrm{H}} 3.35\right)$ to $\mathrm{C}-20\left(\delta_{\mathrm{C}} 37.0\right), \mathrm{C}-24$ $\left(\delta_{\mathrm{C}} 23.5\right)$, and C-30 $\left(\delta_{\mathrm{C}} 26.6\right)$ in the HMBC spectrum of 2 (Figure 2). In addition, correlated proton signals at $\mathrm{H}_{2}-8\left(\delta_{\mathrm{H}} 2.13\right), \mathrm{H}-7\left(\delta_{\mathrm{H}} 5.43\right), \mathrm{H}_{2}-17\left(\delta_{\mathrm{H}} 2.10\right)$, and $\mathrm{H}-18\left(\delta_{\mathrm{H}} 5.19\right)$ were observed in the ${ }^{1} \mathrm{H}-{ }^{1} \mathrm{H}$ COSY spectrum of 2 . Based on these results, 2 was identified as the acyclic triterpenoid, 2,3,5,22,23-pentahydroxy-2,6,10,15,19,23-hexamethyl-tetracosa-6,10,14,18-tetraene (Figure 1) [25].

Table 1. ${ }^{1} \mathrm{H}$ - and ${ }^{13} \mathrm{C}-\mathrm{NMR}$ Spectroscopic data of Compounds 2-4.

\begin{tabular}{|c|c|c|c|c|c|c|}
\hline \multirow{2}{*}{ Position } & \multicolumn{2}{|l|}{$2^{a}$} & \multicolumn{2}{|l|}{$3^{b}$} & \multicolumn{2}{|l|}{$4^{b}$} \\
\hline & $\delta_{H}(J$ in $\mathbf{H z})$ & $\delta_{C}$ & $\delta_{\mathrm{H}}(J$ in $\mathrm{Hz})$ & $\delta_{C}$ & $\delta_{H}(J$ in $\mathbf{H z})$ & $\delta_{C}$ \\
\hline 1 & $1.20, \mathrm{~s}$ & 24.0 & $1.19, \mathrm{~s}$ & 26.4 & $1.15, \mathrm{~s}$ & 26.4 \\
\hline 2 & - & 73.3 & - & 73.1 & - & 73.0 \\
\hline 3 & $3.62, \mathrm{dd}(8.4,3.6)$ & 78.5 & $3.35, \mathrm{dd}(10.8,1.8)$ & 48.2 & 3.34, d (9.6) & 78.1 \\
\hline 4 & $1.63, \mathrm{~m}$ & 36.1 & $2.03, \mathrm{~m}$ & 22.9 & $1.40,1.58, \mathrm{~m}$ & 29.5 \\
\hline 5 & 4.26, dd $(7.6,4.8)$ & 78.6 & $1.55, \mathrm{~m}$ & 42.4 & $2.01, \mathrm{~m}$ & 24.3 \\
\hline 6 & - & 134.9 & - & 73.0 & $4.09, \mathrm{~m}$ & 75.1 \\
\hline 7 & $5.43, \mathrm{t}(6.4)$ & 126.6 & $5.50, \mathrm{dd}(15.6,1.2)$ & 136.7 & - & 151.3 \\
\hline 8 & $2.13, \mathrm{~m}$ & 26.6 & $5.58, \mathrm{dt}(15.6,6.0)$ & 126.7 & $2.01,2.19, \mathrm{~m}$ & 31.0 \\
\hline 9 & $2.05, \mathrm{~m}$ & 39.4 & $2.74, \mathrm{t}(6.6)$ & 30.8 & $1.58,1.65, \mathrm{~m}$ & 35.3 \\
\hline 10 & - & 135.1 & $5.14, \operatorname{td}(7.2,1.2)$ & 122.2 & - & 135.9 \\
\hline 11 & $5.14, \mathrm{~m}$ & 124.7 & - & 135.0 & $5.22, \mathrm{t}(6.6)$ & 125.1 \\
\hline 12 & $1.41, \mathrm{~m}$ & 29.8 & $2.03,2.10, \mathrm{~m}$ & 39.5 & $1.58, \mathrm{~m}$ & 29.6 \\
\hline 13 & $1.59, \mathrm{~m}$ & 39.8 & $1.40,1.58, \mathrm{~m}$ & 29.5 & $2.10, \mathrm{~m}$ & 29.4 \\
\hline 14 & $5.14, \mathrm{~m}$ & 124.9 & $5.18, \mathrm{t}(6.6)$ & 124.9 & $5.14, q(6.6)$ & 124.3 \\
\hline 15 & - & 135.2 & - & 135.2 & - & 135.0 \\
\hline 16 & $2.02, \mathrm{~m}$ & 28.4 & 2.03, m & 36.8 & $2.02, \mathrm{~m}$ & 39.5 \\
\hline 17 & $2.10, \mathrm{~m}$ & 26.6 & $2.10, \mathrm{~m}$ & 26.1 & $2.01,2.10, \mathrm{~m}$ & 26.4 \\
\hline 18 & $5.19, \mathrm{t}(6.4)$ & 125.3 & $5.23, \operatorname{td}(6.6,1.2)$ & 125.5 & $5.14, q(6.6)$ & 124.9 \\
\hline 19 & - & 137.3 & - & 135.9 & - & 135.1 \\
\hline 20 & $2.23, \mathrm{~m}$ & 37.0 & $2.02,2.22, \mathrm{~m}$ & 36.8 & $2.03,2.21, \mathrm{~m}$ & 36.7 \\
\hline 21 & $2.09, \mathrm{~m}$ & 26.2 & $1.58, \mathrm{~m}$ & 29.6 & $1.40,1.58, \mathrm{~m}$ & 29.5 \\
\hline 22 & $3.35, \mathrm{~d}(10.4)$ & 78.9 & $3.35, \mathrm{dd}(10.8,1.8)$ & 78.2 & 3.34, d (9.6) & 78.1 \\
\hline 23 & - & 72.8 & - & 73.1 & - & 73.0 \\
\hline 24 & $1.19, \mathrm{~s}$ & 23.5 & $1.15, \mathrm{~s}$ & 23.4 & $1.19, \mathrm{~s}$ & 23.4 \\
\hline 25 & $1.17, \mathrm{~s}$ & 26.4 & $1.15, \mathrm{~s}$ & 23.3 & $1.19, \mathrm{~s}$ & 23.3 \\
\hline 26 & $1.63, \mathrm{~s}$ & 11.9 & $1.26, \mathrm{~s}$ & 28.1 & $4.87,5.05$, br s & 109.9 \\
\hline 27 & $1.62, \mathrm{~s}$ & 16.1 & $1.60, \mathrm{~s}$ & 16.0 & $1.60, \mathrm{~s}$ & 15.9 \\
\hline 28 & $1.61, \mathrm{~s}$ & 16.2 & $1.61, \mathrm{~s}$ & 15.9 & $1.62, \mathrm{~s}$ & 16.0 \\
\hline 29 & $1.60, \mathrm{~s}$ & 16.2 & $1.61, \mathrm{~s}$ & 15.9 & $1.61, \mathrm{~s}$ & 15.9 \\
\hline 30 & $1.15, \mathrm{~s}$ & 26.6 & $1.19, \mathrm{~s}$ & 26.5 & $1.15, \mathrm{~s}$ & 26.4 \\
\hline
\end{tabular}

${ }^{\mathrm{a}}{ }^{1} \mathrm{H}$ - and ${ }^{13} \mathrm{C}-\mathrm{NMR}$ spectra were recorded at 500 and $125 \mathrm{MHz}$, respectively, in $\mathrm{CDCl}_{3} ;{ }^{\mathrm{b} 1} \mathrm{H}$ - and ${ }^{13} \mathrm{C}-\mathrm{NMR}$ spectra were recorded at 600 and $150 \mathrm{MHz}$, respectively, in $\mathrm{CDCl}_{3}$. 


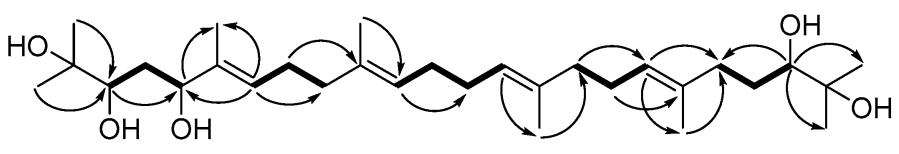

2

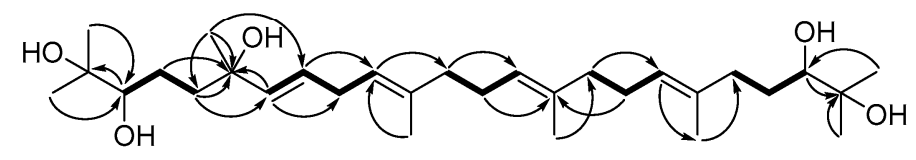

3

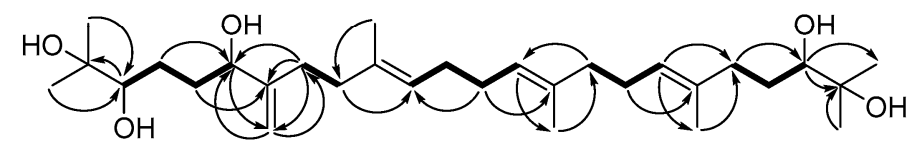

4

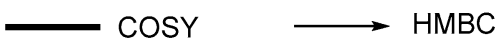

Figure 2. Key COSY and HBMC correlations of Compounds 2-4.

Compound 3 was isolated as a yellow oil with $[\alpha]_{D}^{20}-0.4\left(\mathrm{CHCl}_{3}, c 0.1\right)$. It displayed a peak at $m / z 517.3861$ in the HRESIMS corresponding to $[\mathrm{M}+\mathrm{Na}]^{+}$(calcd. 517.3863), indicating a molecular formula of $\mathrm{C}_{30} \mathrm{H}_{54} \mathrm{O}_{5}$. Comparison of the ${ }^{1} \mathrm{H}-\mathrm{NMR}$ data with those of 2 (Table 1) indicated that 3 had two downfield-shifted olefinic protons at $\delta_{\mathrm{H}} 5.50(1 \mathrm{H}, \mathrm{dd}, J=15.6,1.2 \mathrm{~Hz}, \mathrm{H}-7)$ and $5.58(1 \mathrm{H}$, $\mathrm{dt}, J=15.6,6.0 \mathrm{~Hz}, \mathrm{H}-8)$. The downfield effect indicates the presence of an electron-withdrawing group around these protons. In addition, six methylene groups at $\delta_{\mathrm{H}} 1.58,2.03,2.10,2.10$, and 2.74 (each $2 \mathrm{H}, \mathrm{m}, \mathrm{H}_{2}-13,16,12,17,9$ ), 2.02 and 2.22 (each $1 \mathrm{H}, \mathrm{m}, \mathrm{H}_{2}-20 \mathrm{a}, 20 \mathrm{~b}$ ) attached to an olefinic group, two oxymethine groups at $\delta_{\mathrm{H}} 3.35(1 \mathrm{H}, \mathrm{dd}, J=10.8,1.8 \mathrm{~Hz}, \mathrm{H}-3, \mathrm{H}-22)$, and four terminal methyl groups at $\delta_{\mathrm{H}} 1.15,1.15,1.19$, and 1.19 (each $3 \mathrm{H}, \mathrm{s}, \mathrm{H}_{3}-24,25,1,30$ ) were detected. The ${ }^{13} \mathrm{C}-\mathrm{NMR}$ spectrum of 3 (Table 1 ) revealed the presence of 30 carbons, and the connectivity of the proton and carbon atoms was elucidated via DEPT and HMQC analyses. In the ${ }^{13} \mathrm{C}-\mathrm{NMR}$ spectrum, the three oxygenated quaternary carbons $C-6\left(\delta_{C} 73.0\right), C-2\left(\delta_{C} 73.1\right)$, and C-23 $\left(\delta_{C} 73.1\right)$ were elucidated via DEPT and HMQC. Detailed 2D correlation analysis identified long-range coupling from $\mathrm{H}-7\left(\delta_{\mathrm{H}} 5.50\right)$ to $\mathrm{C}-6\left(\delta_{\mathrm{C}} 73.0\right), \mathrm{C}-8\left(\delta_{\mathrm{C}} 126.7\right)$, and $\mathrm{C}-9\left(\delta_{\mathrm{C}} 30.8\right)$, from $\mathrm{H}_{2}-5\left(\delta_{\mathrm{H}} 1.55\right)$ to $\mathrm{C}-4$ $\left(\delta_{\mathrm{C}} 22.9\right), \mathrm{C}-6\left(\delta_{\mathrm{C}} 73.0\right)$, and $\mathrm{C}-7\left(\delta_{\mathrm{C}} 136.7\right)$, and from $\mathrm{H}_{3}-26\left(\delta_{\mathrm{H}} 1.26\right)$ to $\mathrm{C}-5\left(\delta_{\mathrm{C}} 42.4\right), \mathrm{C}-6\left(\delta_{\mathrm{C}} 73.0\right)$, and C-7 $\left(\delta_{C}\right.$ 136.7) (Figure 2). The ${ }^{1} \mathrm{H}^{-1} \mathrm{H}$ COSY spectrum of 3 was from the $\mathrm{H}_{2}-9\left(\delta_{\mathrm{H}} 2.74\right) s p^{3}$ methylene proton to $\mathrm{H}-8\left(\delta_{\mathrm{H}} 5.58\right)$ and $\mathrm{H}-10\left(\delta_{\mathrm{H}} 5.14\right)$. Therefore, the structure of 3 had a newly attached hydroxy group at the C-6 position. This hydroxy group influenced the shift of the double bond position from H-6 to H-7. Based on these data, 3 was identified as a new acyclic triterpenoid, 2,3,6,22,23-pentahydroxy-2,6,11,15,19,23-hexamethyl-tetracosa-7,10,14,18-tetraene (Figure 1).

Compound 4 was isolated as a yellow oil with $[\alpha]_{\mathrm{D}}^{20}+13.3\left(\mathrm{CHCl}_{3}, c 0.1\right)$. It displayed a peak at $m / z$ 493.3898 in the HRESIMS corresponding to $[\mathrm{M}-\mathrm{H}]^{-}$(calcd. 493.3898), indicating a molecular formula of $\mathrm{C}_{30} \mathrm{H}_{54} \mathrm{O}_{5}$. Comparison of the ${ }^{1} \mathrm{H}-\mathrm{NMR}$ data with those of 3 (Table 1) indicated that 4 had three olefinic groups at $\delta_{\mathrm{H}} 5.14(1 \mathrm{H}, \mathrm{q}, J=6.6 \mathrm{~Hz}, \mathrm{H}-14,-18)$, and $5.22(1 \mathrm{H}, \mathrm{t}, J=6.6 \mathrm{~Hz}, \mathrm{H}-11)$ and two terminal olefinic protons at $\delta_{\mathrm{H}} 4.87\left(1 \mathrm{H}, \mathrm{brs}, \mathrm{H}_{2}-26 \mathrm{a}\right)$ and $5.05\left(1 \mathrm{H}, \mathrm{brs}, \mathrm{H}_{2}-26 \mathrm{~b}\right)$, which were supported by the DEPT and COSY spectra. In addition, two methylene group signals between two hydroxy groups were 
observed at $\delta_{\mathrm{H}} 1.58\left(2 \mathrm{H}, \mathrm{m}, \mathrm{H}_{2}-4\right)$ and $2.01\left(2 \mathrm{H}, \mathrm{m}, \mathrm{H}_{2}-5\right)$, three oxymethine groups were observed at $\delta_{\mathrm{H}}$ $3.34(1 \mathrm{H}, \mathrm{d}, J=9.6 \mathrm{~Hz}, \mathrm{H}-3,-22)$, and $4.09(1 \mathrm{H}, \mathrm{m}, \mathrm{H}-6)$, and four terminal methyl groups were observed at $\delta_{\mathrm{H}} 1.15,1.15,1.19$, and 1.19 (each $3 \mathrm{H}, \mathrm{s}, \mathrm{H}_{3}-1,30,24,25$ ). In the ${ }^{13} \mathrm{C}-\mathrm{NMR}$ spectrum (Table 1), three oxymethine carbons, $C-6\left(\delta_{C} 75.1\right), C-3\left(\delta_{C} 78.1\right)$, and C-22 $\left(\delta_{C} 78.1\right)$, were elucidated via DEPT and HMQC analyses. Detailed 2D correlation analysis between C- 6 and terminal olefinic protons revealed long-range couplings from $\mathrm{H}_{2}-5\left(\delta_{\mathrm{H}} 2.01\right)$ to $\mathrm{C}-6\left(\delta_{\mathrm{C}} 75.1\right)$ and $\mathrm{C}-7\left(\delta_{\mathrm{C}} 151.3\right)$, from H-6 $\left(\delta_{\mathrm{H}} 4.09\right)$ to $\mathrm{C}-5$ $\left(\delta_{C} 24.3\right)$ and $C-26\left(\delta_{C} 109.9\right)$, from $\mathrm{H}_{2}-8\left(\delta_{\mathrm{H}} 2.19\right)$ to $C-6\left(\delta_{C} 75.1\right), \mathrm{C}-26\left(\delta_{\mathrm{C}} 109.9\right)$, and $\mathrm{C}-7\left(\delta_{\mathrm{C}} 151.3\right)$, and from $\mathrm{H}_{2}-26\left(\delta_{\mathrm{H}} 4.87\right.$ and 5.05) to C-6 $\left(\delta_{\mathrm{C}} 75.1\right)$ and $\mathrm{C}-8\left(\delta_{\mathrm{C}} 31.0\right)$. Therefore, Compound 4 had a secondary alcohol group (C-6) instead of the methyl group at the C-6 of 3 . This hydroxy group influenced the movement of the double bond position, and terminal olefinic protons appeared at the C-7 position. Based on these results, Compound 4 was identified as a new acyclic triterpenoid, 2,3,6,22,23-pentahydroxy-2,10,15,19,23-hexamethyl-7-methylenetetracosa-10,14,18-triene.

We applied the modified Mosher's method to determine the absolute configuration of the three chiral centers at C-3, C-5, and C-22 in 2, and corresponding to the $\Delta \delta_{\mathrm{H}}$ pattern for the stereochemistry of secondary diols reported by Freire et al. [26-28]. The mono- or tris-(S)-MTPA esters (2a, 2c) and -(R)-MTPA esters $(\mathbf{2} \mathbf{b}, \mathbf{2} \mathbf{d})$ were prepared by treating $\mathbf{2}$ with $(R)-$, and $(S)$-MTPA chloride, respectively. The difference in the chemical shift values $\left(\Delta \delta_{\mathrm{H}}=\delta_{S}-\delta_{R}\right)$ of $(S)$-MTPA (2a, 2c $)$, and (R)-MTPA ester derivatives $(\mathbf{2} \mathbf{b}, \mathbf{2 d})$ was calculated to assign the absolute configuration of $\mathbf{2}$ (Figure 3). Based on the results summarized in Figure 3, the absolute configurations of C-3, C-5, and C-22 in 2 were determined as $R, S$ and $R$, respectively. To elucidate absolute configuration of Compound 3, a pair of MTPA esters (3a and $\mathbf{3 b}$ ) were prepared in the same manner. As shown in Figure 3, the absolute configurations of $\mathrm{C}-3$ and C-22 in 3 were assigned as $R$ and $R$, respectively. Unfortunately, we were unable to prepare the relevant MTPA ester derivatives to determine the absolute configuration of 4 , and further studies are required to elucidate stereostructure of acyclic triterpenoid (4).

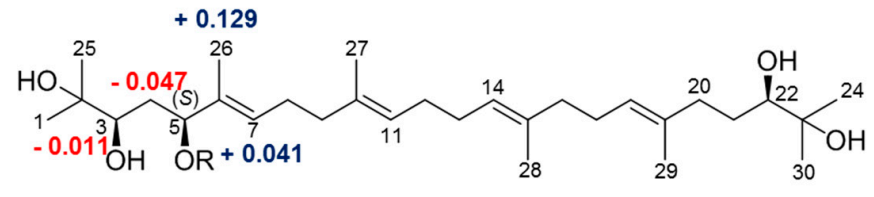

$2 a$ and $2 b$

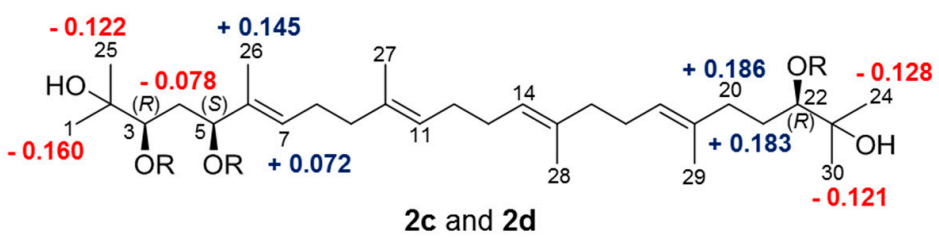

2a and $2 c \quad R=(S)-M T P A$

$2 b$ and $2 d \quad R=(R)-M T P A$

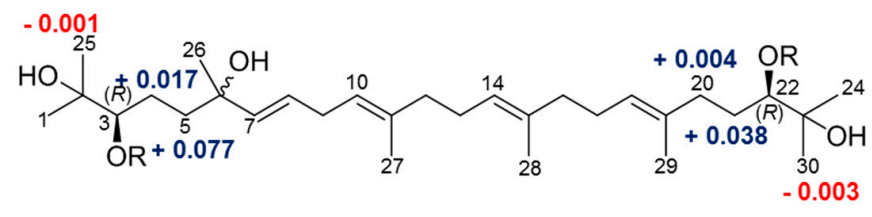

$3 a$ and $3 b$

3a $R=(S)-M T P A$

3b $R=(R)-M T P A$

Figure 3. $\Delta \delta\left(\delta_{S}-\delta_{R}\right)$ values in ppm for the MTPA esters of 2 and 3. 


\subsection{IL-6/STAT3 Inhibitory Effects of Acyclic Triterpenoids 1-4}

Compounds 1-4 were tested for their inhibitory effects on STAT3-dependent luciferase activity induced by IL-6. Hep3B cells stably transformed with the pStat3-Luc plasmid were stimulated with IL-6 (10 ng $/ \mathrm{mL})$ for $12 \mathrm{~h}$ in the presence or absence of Compounds 1-4, and STAT3-dependent promoter activity was measured [29]. Compounds 1-4 inhibited IL-6-induced STAT3 activity in a dose-dependent fashion, with $\mathrm{IC}_{50}$ values of $0.67,0.71,2.18$ and $2.99 \mu \mathrm{M}$ (Figure 4). These four acyclic triterpenoids showed more potent inhibitory activity on STAT3-dependent luciferase activity than that of genistein as the positive control ( $\mathrm{IC}_{50}$ value, $15.0 \mu \mathrm{M}$ in this assay system) [29]. Additionally, Compounds 1-4 were non-cytotoxic at the $\mathrm{IC}_{50}$ dose indicated in this study (see Figure S34 in Supplementary Materials).

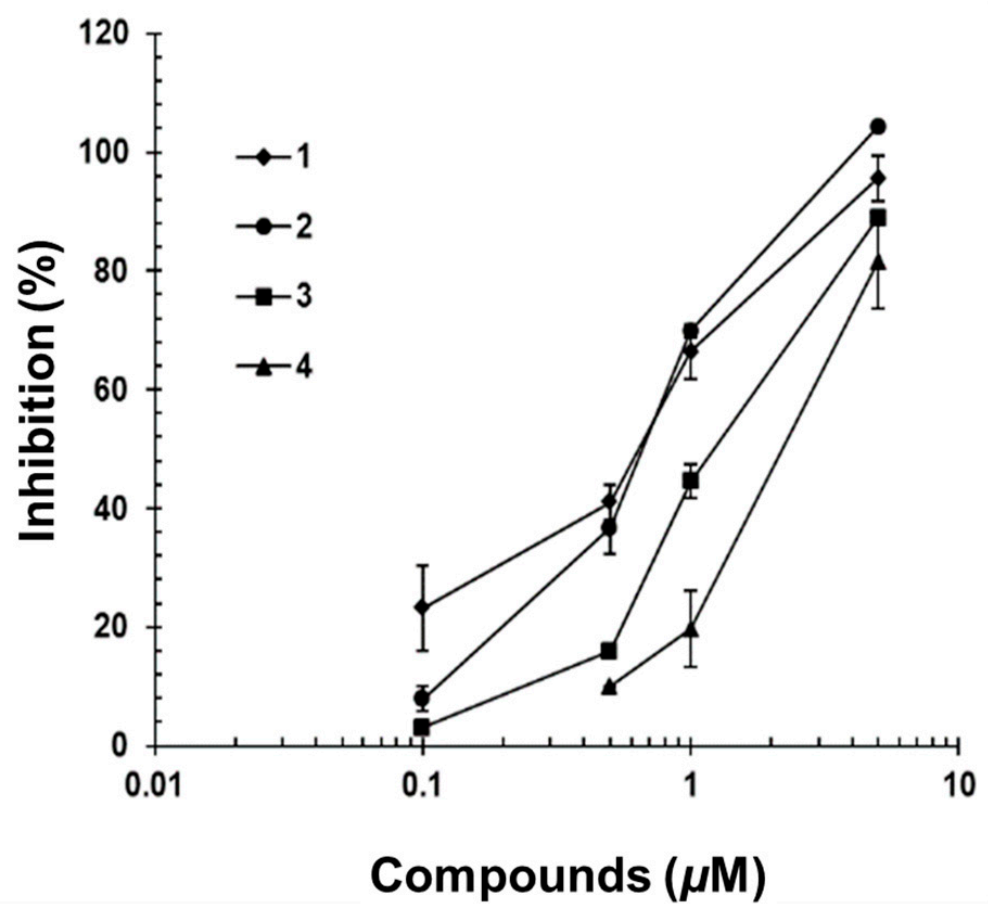

Figure 4. Inhibitory effects of 1-4 on IL-6/STAT3 transcriptional activity in Hep3B cells. The pSTAT3-inducible luciferase activity was measured by luciferase assay. Three independent experiments were performed, and the results are presented as the means \pm standard error (S.E.).

The IL-6-induced JAK2/STAT3 signaling pathway plays a positive role in inflammation and neoplasia [30]. The phosphorylation of JAK2 and STAT3 leads to dimerization of STAT3 and translocation to the nucleus, where it transcribes pro-inflammatory cytokine genes, such as IFN- $\gamma$, IL-17, and IL-1 $\beta$ [31]. To determine whether the inhibitory effects on IL-6/STAT3 are dependent on JAK2/STAT3 phosphorylation, we evaluated the protein level by Western blotting analysis. As shown in Figure 5, A. katsumadai EtOH extract and Compounds $\mathbf{1}$ and $\mathbf{2}$ inhibited IL-6-stimulated phosphorylation of JAK2 and STAT3 in a concentrations-dependent manner. In particular, Compounds $\mathbf{1}$ and 2, which were major constituents of the A. katsumadai EtOH extract (see Figure S35 in Supplementary Materials), were significantly responsible for inhibiting IL-6/STAT3 activation. 


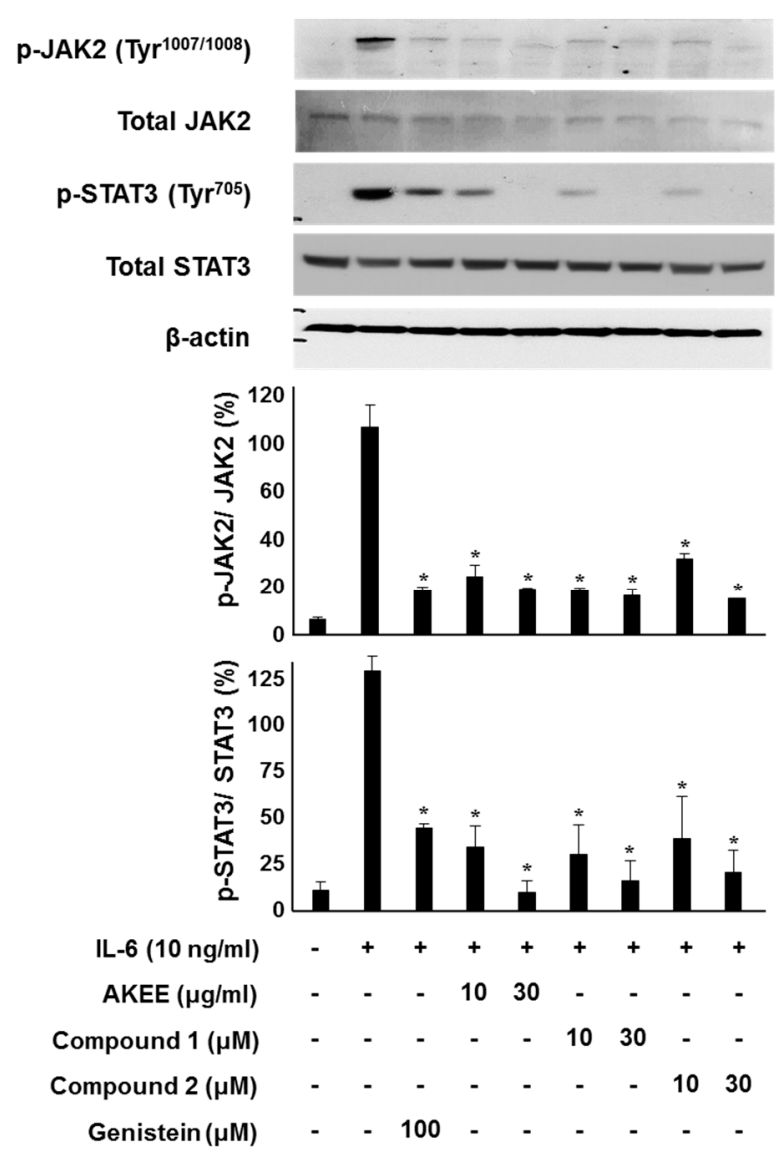

Figure 5. Inhibitory effects of A. katsumadai EtOH extract (AKEE) and its compounds (1 and 2) on IL-6-induced JAK2 and STAT3 phosphorylation in U266 cells. Cells were pre-treated with samples for $1 \mathrm{~h}$ at the indicated concentrations and were then treated with IL-6 $(10 \mathrm{ng} / \mathrm{mL})$ for $20 \mathrm{~min}$. Phosphorylated JAK2 and STAT3 was analyzed by Western blotting. The ratios of p-JAK2 or p-STAT3/ $\beta$-actin were measured using ImageJ software $(1.48 \mathrm{v}$, US National Institutes of Health, Bethesda, MD, USA). The data were analyzed by $t$-test compared with the IL-6-induced group, and an asterisk $\left.{ }^{*}\right)$ indicates significant difference $(p<0.05)$.

\section{Materials and Methods}

\subsection{General Experimental Procedures}

${ }^{1} \mathrm{H}-\mathrm{NMR}(300,500$ and $600 \mathrm{MHz}),{ }^{13} \mathrm{C}-\mathrm{NMR}(75,125$ and $150 \mathrm{MHz}), \mathrm{HMQC}$, and HMBC spectra were obtained on a Varian Unity 300, Bruker Biospin Avance 500, and JEOL JNM-ECA600 spectrometer, with $\mathrm{CDCl}_{3}$ as a solvent. ESI-MS was conducted using a Shimadzu LCMS-IT-TOF mass spectrometer. Optical rotations were determined on a JASCO DIP-370 polarimeter. The HPLC system consisted of a Hitachi L-2130 pump, Hitachi UV detector L-2400, and Capcell Pak C18 column $(20 \times 250 \mathrm{~mm}$, Shiseido, Tokyo, Japan). Reversed-phase column chromatography was conducted using RP-C ${ }_{18}$ silica gel (ODS-A, $250 \times 20 \mathrm{~mm}$, YMC Co. Ltd., Kyoto, Japan), and silica gel column chromatography was conducted using Kieselgel 60 (70-230 and 200-400 mesh, Merck, Darmstadt, Germany). TLC was conducted using Kieselgel $60 \mathrm{~F}_{254}$ plates (Merck).

\subsection{Extraction and Isolation}

The seeds of A. katsumadai were purchased at a herbal market in Daejeon, Korea. The authenticity of the plants was confirmed by Prof. Y. H. Kim, at the College of Pharmacy of Chungnam National University (Daejeon, Korea). A voucher specimen (PBC-386A) was deposited in the Korea Plant Extract 
Bank at the Korea Research Institute of Bioscience and Biotechnology. Dried seeds of A. katsumadai $(1.8 \mathrm{~kg})$ were extracted with $\mathrm{EtOH}(10 \mathrm{~L})$ for 7 days at room temperature. The ethanol extract was evaporated in vacuo to yield a residue $(180 \mathrm{~g})$. The residue was suspended in distilled $\mathrm{H}_{2} \mathrm{O}(3 \mathrm{~L})$ and extracted with $\mathrm{CHCl}_{3}(10 \mathrm{~L})$. The $\mathrm{CHCl}_{3}$-soluble components were then evaporated in vacuo, and the resulting extract (85 g) was subjected to silica gel (Kieselgel 60, 230-400 mesh, 150 g, Merck, Darmstadt, Germany) column chromatography using a gradient of $\mathrm{CHCl}_{3}-\mathrm{CH}_{3} \mathrm{OH}(100: 0,90: 1,70: 1$, 50:1, 30:1, 15:1, 5:1 and 1:1; each $3 \mathrm{~L}, v / v$ ) as eluent to yield 22 fractions (F1-22) on the TLC profile. F8 (2.4 g) was subjected to reverse-phase column chromatography (100 g) and was eluted with $\mathrm{CH}_{3} \mathrm{OH}-\mathrm{H}_{2} \mathrm{O}(60: 1,70: 1,80: 1,90: 1$ and 100:0; each $2 \mathrm{~L}, v / v)$, to yield six sub-fractions (F8-1, -6) based on the TLC profile. F8-3 (1.0 g) was separated by semi-preparative HPLC (YMC ODS-H80, flow rate: $6 \mathrm{~mL} / \mathrm{min})$ eluted with $\mathrm{CH}_{3} \mathrm{CN}-\mathrm{H}_{2} \mathrm{O}(80: 1, v / v)$ to yield 1 (300 mg, $\left.t_{\mathrm{R}} 40 \mathrm{~min}\right)$. F9 (700 mg) was subjected to reverse-phase column chromatography $(100 \mathrm{~g})$ eluted with $\mathrm{CH}_{3} \mathrm{OH}-\mathrm{H}_{2} \mathrm{O}(50: 1,60: 1$, 70:1, 80:1, 90:1, and 100:0; each $2 \mathrm{~L}, v / v)$ to yield seven sub-fractions (F9-1, -7). F9-3 (300 mg) was successively separated by preparative $\mathrm{HPLC}\left(\mathrm{CH}_{3} \mathrm{CN}-\mathrm{H}_{2} \mathrm{O}, 70: 1, v / v\right)$ to yield $2\left(100 \mathrm{mg}, t_{\mathrm{R}} 30 \mathrm{~min}\right)$. F16 (8.4 g) was subjected to reverse-phase column chromatography eluted with $\mathrm{CH}_{3} \mathrm{OH}-\mathrm{H}_{2} \mathrm{O}(2: 3,1: 1$, $3: 2,7: 3,4: 1,9: 1$, and 100:0; each $500 \mathrm{~m} \mathrm{~L}, v / v)$, to yield seven sub-fractions (F16-1, -7). F16-4 was subjected to reverse-phase column chromatography eluted with $\mathrm{CH}_{3} \mathrm{CN}-\mathrm{H}_{2} \mathrm{O}(2: 3,1: 1,3: 2,7: 3,4: 1,9: 1$, and 100:0; each $300 \mathrm{~mL}, v / v$ ) to yield seven sub-fractions (F16-4-1, -7). F16-4-6 (538 mg) was eluted with $\mathrm{CH}_{3} \mathrm{OH}-\mathrm{H}_{2} \mathrm{O}(4: 1, v / v)$ and was subjected to further separation by preparative HPLC (Capcell Pak $\mathrm{C}_{18}$, flow rate: $5 \mathrm{~mL} / \mathrm{min}$ ) to obtain five fractions. F16-4-6-3 was purified by semi-preparative HPLC $\left(\mathrm{CH}_{3} \mathrm{CN}-\mathrm{H}_{2} \mathrm{O}, 11: 9\right.$, flow rate: $\left.5 \mathrm{~mL} / \mathrm{min}\right)$ to yield 3 (30 mg, $\left.t_{\mathrm{R}} 38 \mathrm{~min}\right)$. F16-4-6-5 was purified by preparative $\mathrm{HPLC}\left(\mathrm{CH}_{3} \mathrm{CN}-\mathrm{H}_{2} \mathrm{O}, 3: 2\right.$, flow rate: $\left.5 \mathrm{~mL} / \mathrm{min}\right)$ to yield $4\left(32 \mathrm{mg}, t_{\mathrm{R}} 45 \mathrm{~min}\right)$.

2,3,22,23-Tertrahydroxy-2,6,10,15,19,23-hexamethyl-tetracosa-6,10,14,18-tetraene (1). Yellow oil; $\mathrm{C}_{30} \mathrm{H}_{54} \mathrm{O}_{4}$; $[\alpha]_{\mathrm{D}}^{20}+18.1\left(c 1.0, \mathrm{CHCl}_{3}\right)$; IR (neat) $v_{\max } 3400,2950 \mathrm{~cm}^{-1}$; ESI-MS: $m / z 501[\mathrm{M}+\mathrm{Na}]^{+} ;{ }^{1} \mathrm{H}-\mathrm{NMR}$ $\left(300 \mathrm{MHz} \mathrm{CDCl}_{3}\right) \delta_{\mathrm{H}} 5.18(2 \mathrm{H}, \mathrm{m}, \mathrm{H}-7, \mathrm{H}-18), 5.13(2 \mathrm{H}, \mathrm{m}, \mathrm{H}-11, \mathrm{H}-14), 3.36$ (2H, dd, J = 2.0, 10.5 Hz, H-3, H-22), 2.23 (2H, m, H2-5a, H2-20a), 2.08 (2H, m, H-8, H-17), 2.06 (2H, m, H2-5b, H2-20b), 2.01 (2H, $\left.\mathrm{m}, \mathrm{H}_{2}-9, \mathrm{H}_{2}-16\right), 1.99$ (2H, m, H $\left.\mathrm{H}_{2}-12, \mathrm{H}_{2}-13\right), 1.59$ (3H, s, $\left.\mathrm{H}_{3}-27, \mathrm{H}_{3}-28\right), 1.58,\left(2 \mathrm{H}, \mathrm{m}, \mathrm{H}_{2}-4 \mathrm{a}, \mathrm{H}_{2}-21 \mathrm{a}\right)$, $1.61\left(3 \mathrm{H}, \mathrm{s}, \mathrm{H}_{3}-26, \mathrm{H}_{3}-29\right), 1.40\left(2 \mathrm{H}, \mathrm{m}, \mathrm{H}_{2}-4 \mathrm{~b}, \mathrm{H}_{2}-21 \mathrm{~b}\right), 1.19$ (3H, s, H3-1, H -24$), 1.15\left(3 \mathrm{H}, \mathrm{s}, \mathrm{H}_{3}-25\right.$, $\left.\mathrm{H}_{3}-30\right) ;{ }^{13} \mathrm{C}-\mathrm{NMR}\left(75 \mathrm{MHz}, \mathrm{CDCl}_{3}\right) \delta_{\mathrm{C}} 15.88$ (C-27, C-28), 15.95 (C-26, C-29), 23.23 (C-25, C-30), 26.36 (C-1, C-24), 26.47 (C-8, C-17), 28.17 (C-9, C-16), 29.64 (C-4, C-21), 36.77 (C-5, C-20), 39.61 (C-12, C-13), 72.99 (C-2, C-23), 78.23 (C-3, C-22), 124.40 (C-11, C-14), 125.01 (C-7, C-18), 134.79 (C-10, C-15), 134.91 (C-6, C-19).

2,3,5,22,23-Pentahydroxy-2,6,10,15,19,23-hexamethyl-tetracosa-6,10,14,18-tetraene (2). Yellow oil; $\mathrm{C}_{30} \mathrm{H}_{54} \mathrm{O}_{5}$; $[\alpha]_{\mathrm{D}}^{20}+4.8\left(c\right.$ 1.0, $\left.\mathrm{CHCl}_{3}\right)$; IR (neat): $v_{\max } 3400,2900 \mathrm{~cm}^{-1} ; \mathrm{UV}(\mathrm{MeOH}) \lambda_{\max }(\log \varepsilon) \mathrm{nm}: 210(2.51)$; ${ }^{1} \mathrm{H}-\mathrm{NMR}\left(500 \mathrm{MHz}, \mathrm{CDCl}_{3}\right)$ and ${ }^{13} \mathrm{C}-\mathrm{NMR}\left(125 \mathrm{MHz}^{\mathrm{CDCl}} \mathrm{CDC}_{3}\right.$ ) spectra, see Table 1 ; HRESI-MS: $\mathrm{m} / z$ $493.3897[\mathrm{M}-\mathrm{H}]^{-}$(calcd. for $\mathrm{C}_{30} \mathrm{H}_{53} \mathrm{O}_{5}, 493.3893$ ).

2,3,6,22,23-Pentahydroxy-2,6,11,15,19,23-hexamethyl-tetracosa-7,10,14,18-tetraene (3). Yellow oil; $\mathrm{C}_{30} \mathrm{H}_{54} \mathrm{O}_{5}$; $[\alpha]_{\mathrm{D}}^{20}-0.4$ ( $\left.0.1, \mathrm{CHCl}_{3}\right)$; IR (MeOH): $v_{\max } 3300,2950,1450,1050 \mathrm{~cm}^{-1} ; \mathrm{UV}(\mathrm{MeOH}) \lambda_{\max }(\log \varepsilon) \mathrm{nm}: 205$ (2.42); ${ }^{1} \mathrm{H}-\mathrm{NMR}\left(600 \mathrm{MHz}, \mathrm{CDCl}_{3}\right)$ and ${ }^{13} \mathrm{C}-\mathrm{NMR}\left(150 \mathrm{MHz}, \mathrm{CDCl}_{3}\right)$ spectra, see Table 1 ; HRESI-MS: $m / z$ 517.3861 [M + Na $]^{+}$(calcd. for $\mathrm{C}_{30} \mathrm{H}_{54} \mathrm{O}_{5} \mathrm{Na}$, 517.3863).

2,3,6,22,23-Pentahydroxy-2,10,15,19,23-hexamethyl-7-methylenetetracosa-10,14,18-triene (4). Yellow oil; $\mathrm{C}_{30} \mathrm{H}_{54} \mathrm{O}_{5} ;[\alpha]_{\mathrm{D}}^{20}+13.3\left(c 0.1, \mathrm{CHCl}_{3}\right) ; \mathrm{IR}(\mathrm{MeOH}): v_{\max } 3300,2950,1050 \mathrm{~cm}^{-1} ; \mathrm{UV}(\mathrm{MeOH}) \lambda_{\max }(\log \varepsilon)$ nm: 205 (2.34); ${ }^{1} \mathrm{H}-\mathrm{NMR}\left(600 \mathrm{MHz}, \mathrm{CDCl}_{3}\right)$ and ${ }^{13} \mathrm{C}-\mathrm{NMR}\left(150 \mathrm{MHz}, \mathrm{CDCl}_{3}\right)$ spectra, see Table 1; HRESI-MS: $m / z 493.3899[\mathrm{M}-\mathrm{H}]^{-}$(calcd. for $\mathrm{C}_{30} \mathrm{H}_{53} \mathrm{O}_{5}, 493.3898$ ).

\section{3. (R)- and (S)-MTPA Ester of Compounds 2-3}

Compounds 2-3 (4 mg) were dissolved in pyridine- $d_{5}(10 \mathrm{~mL})$, and $(R)$ - or $(S)-\mathrm{MTPA}-\mathrm{Cl}(10 \mu \mathrm{L})$ and DMAP (2 mg) were added. The mixture was transferred vials under an $\mathrm{N}_{2}$ gas stream. The each 
vials were incubated in a water bath for $4 \mathrm{~h}\left(40^{\circ} \mathrm{C}\right)$. The reactions afforded $(S)$ - or $(R)$-MTPA ester derivatives $2 S, 3 S$, and $2 R, 3 R$, and each residues were purified by preparative HPLC using a $C_{18}$ column (Phenomenex kinetex $\mathrm{C}_{18}, 150 \times 21.0 \mathrm{~mm}$ ), eluting with a gradient solvent system composed of $\mathrm{H}_{2} \mathrm{O} / \mathrm{CH}_{3} \mathrm{OH}(40: 60 \rightarrow 0: 100, v / v)$. The ${ }^{1} \mathrm{H}-\mathrm{NMR}$ spectra of each derivative were obtained from the reaction.

5-Mono-MTPA Ester of 2 (2a). ${ }^{1} \mathrm{H}-\mathrm{NMR}$ (pyridine- $\left.d_{5}, 600 \mathrm{MHz}\right) \delta_{\mathrm{H}} 6.41(1 \mathrm{H}, \mathrm{dd}, J=10.8,4.2 \mathrm{~Hz}, \mathrm{H}-5)$, $5.94(1 \mathrm{H}, \mathrm{t}, J=6.0 \mathrm{~Hz}, \mathrm{H}-7), 5.39(1 \mathrm{H}, \mathrm{t}, J=7.2, \mathrm{H}-18), 5.31(1 \mathrm{H}, \mathrm{br} \mathrm{s}, \mathrm{H}-11), 5.26(1 \mathrm{H}, \mathrm{br} \mathrm{s}, \mathrm{H}-14), 3.77$ (1H, m, H-3), $3.73(1 \mathrm{H}, \mathrm{m}, \mathrm{H}-22), 2.70\left(1 \mathrm{H}, \mathrm{m}, \mathrm{H}_{2}-20 \mathrm{a}\right), 2.51\left(1 \mathrm{H}, \mathrm{m}, \mathrm{H}_{2}-4 \mathrm{a}\right), 2.40\left(5 \mathrm{H}, \mathrm{m}, \mathrm{H}_{2}-4 \mathrm{~b},-8 \mathrm{a}\right.$, -13a, -17a, -20b), $2.11\left(8 \mathrm{H}, \mathrm{m}, \mathrm{H}_{2}-8 \mathrm{~b},-9,12 \mathrm{a},-13 \mathrm{~b},-16,-17 \mathrm{~b}\right), 1.83\left(3 \mathrm{H}, \mathrm{s}, \mathrm{H}_{3}-26\right), 1.82\left(2 \mathrm{H}, \mathrm{m}, \mathrm{H}_{2}-21\right)$, 1.71, $\left(3 \mathrm{H}, \mathrm{s}, \mathrm{H}_{3}-27\right), 1.66,\left(3 \mathrm{H}, \mathrm{s}, \mathrm{H}_{3}-28\right), 1.62\left(3 \mathrm{H}, \mathrm{s}, \mathrm{H}_{3}-29\right), 1.54\left(3 \mathrm{H}, \mathrm{s}, \mathrm{H}_{3}-1\right), 1.52\left(3 \mathrm{H}, \mathrm{s}, \mathrm{H}_{3}-24\right), 1.51$ $\left(3 \mathrm{H}, \mathrm{s}, \mathrm{H}_{3}-25\right), 1.48\left(3 \mathrm{H}, \mathrm{s}, \mathrm{H}_{3}-30\right)$.

5-Mono-MTPA Ester of $2(\mathbf{2 b}) .{ }^{1} \mathrm{H}-\mathrm{NMR}$ (pyridine- $\left.d_{5}, 600 \mathrm{MHz}\right) \delta_{\mathrm{H}} 6.36(1 \mathrm{H}, \mathrm{dd}, J=10.2,4.2 \mathrm{~Hz}, \mathrm{H}-5)$, $5.90(1 \mathrm{H}, \mathrm{t}, J=5.4 \mathrm{~Hz}, \mathrm{H}-7), 5.39(1 \mathrm{H}, \mathrm{t}, J=7.2, \mathrm{H}-18), 5.31(1 \mathrm{H}, \mathrm{br} \mathrm{s}, \mathrm{H}-11), 5.27(1 \mathrm{H}, \mathrm{br} \mathrm{s}, \mathrm{H}-14), 3.78$ (2H, m, H-3, -22), $2.71\left(1 \mathrm{H}, \mathrm{m}, \mathrm{H}_{2}-20 \mathrm{a}\right), 2.56\left(1 \mathrm{H}, \mathrm{m}, \mathrm{H}_{2}-4 \mathrm{a}\right), 2.36\left(5 \mathrm{H}, \mathrm{m}, \mathrm{H}_{2}-4 \mathrm{~b},-8 \mathrm{a},-13 \mathrm{a},-17 \mathrm{a},-20 \mathrm{~b}\right)$, $2.08\left(8 \mathrm{H}, \mathrm{m}, \mathrm{H}_{2}-8 \mathrm{~b},-9,12 \mathrm{a},-13 \mathrm{~b},-16,-17 \mathrm{~b}\right), 1.82\left(2 \mathrm{H}, \mathrm{m}, \mathrm{H}_{2}-21\right), 1.71\left(3 \mathrm{H}, \mathrm{s}, \mathrm{H}_{3}-26\right), 1.66,\left(3 \mathrm{H}, \mathrm{s}, \mathrm{H}_{3}-27\right)$, 1.62, $\left(3 \mathrm{H}, \mathrm{s}, \mathrm{H}_{3}-28\right), 1.61\left(3 \mathrm{H}, \mathrm{s}, \mathrm{H}_{3}-29\right), 1.55\left(6 \mathrm{H}, \mathrm{s}, \mathrm{H}_{3}-1,-24\right), 1.52\left(3 \mathrm{H}, \mathrm{s}, \mathrm{H}_{3}-25\right), 1.51\left(3 \mathrm{H}, \mathrm{s}, \mathrm{H}_{3}-30\right)$.

3,5,22-Tris-MTPA Ester of 2 (2c). ${ }^{1} \mathrm{H}-\mathrm{NMR}$ (pyridine- $\left.d_{5}, 600 \mathrm{MHz}\right) \delta_{\mathrm{H}} 6.06(1 \mathrm{H}, \mathrm{dd}, J=11.4,4.2 \mathrm{~Hz}$, $\mathrm{H}-5), 6.00(1 \mathrm{H}, \mathrm{t}, J=6.6 \mathrm{~Hz}, \mathrm{H}-7), 5.53(1 \mathrm{H}, \mathrm{d}, J=10.2, \mathrm{H}-3), 5.39(1 \mathrm{H}, \mathrm{d}, J=10.2 \mathrm{~Hz}, \mathrm{H}-22), 5.36(1 \mathrm{H}, \mathrm{t}$, $J=6.6 \mathrm{~Hz}, \mathrm{H}-18), 5.30(2 \mathrm{H}, \mathrm{m}, \mathrm{H}-11,-14), 2.75\left(1 \mathrm{H}, \mathrm{m}, \mathrm{H}_{2}-20 \mathrm{a}\right), 2.36\left(1 \mathrm{H}, \mathrm{m}, \mathrm{H}_{2}-4 \mathrm{a}\right), 2.30\left(5 \mathrm{H}, \mathrm{m}, \mathrm{H}_{2}-4 \mathrm{~b}\right.$, $-8 \mathrm{a},-13 \mathrm{a},-17 \mathrm{a},-20 \mathrm{~b}), 2.18\left(8 \mathrm{H}, \mathrm{m}, \mathrm{H}_{2}-8 \mathrm{~b},-9,12 \mathrm{a},-13 \mathrm{~b},-16,-17 \mathrm{~b}\right), 1.95\left(2 \mathrm{H}, \mathrm{m}, \mathrm{H}_{2}-21\right), 1.81\left(3 \mathrm{H}, \mathrm{s}, \mathrm{H}_{3}-26\right)$, 1.66, (3H, s, $\left.\mathrm{H}_{3}-27\right), 1.65,\left(3 \mathrm{H}, \mathrm{s}, \mathrm{H}_{3}-28\right), 1.62\left(3 \mathrm{H}, \mathrm{s}, \mathrm{H}_{3}-29\right), 1.40\left(3 \mathrm{H}, \mathrm{s}, \mathrm{H}_{3}-1\right), 1.39\left(3 \mathrm{H}, \mathrm{s}, \mathrm{H}_{3}-24\right), 1.33$ $\left(3 \mathrm{H}, \mathrm{s}, \mathrm{H}_{3}-25\right), 1.32\left(3 \mathrm{H}, \mathrm{s}, \mathrm{H}_{3}-30\right)$.

3,5,22-Tris-MTPA Ester of 2 (2d). ${ }^{1} \mathrm{H}-\mathrm{NMR}$ (pyridine- $\left.d_{5}, 600 \mathrm{MHz}\right) \delta_{\mathrm{H}} 6.36(1 \mathrm{H}, \mathrm{dd}, J=10.2,4.2 \mathrm{~Hz}$, H-5), $5.90(1 \mathrm{H}, \mathrm{m}, \mathrm{H}-7), 5.55(1 \mathrm{H}, \mathrm{d}, J=10.8, \mathrm{H}-3), 5.32(1 \mathrm{H}, \mathrm{m}, \mathrm{H}-22), 5.27(1 \mathrm{H}, \mathrm{m}, \mathrm{H}-18), 5.20(2 \mathrm{H}, \mathrm{m}$, $\mathrm{H}-11,-14), 2.56\left(1 \mathrm{H}, \mathrm{m}, \mathrm{H}_{2}-20 \mathrm{a}\right), 2.44\left(1 \mathrm{H}, \mathrm{m}, \mathrm{H}_{2}-4 \mathrm{a}\right), 2.38$ (5H, m, $\left.\mathrm{H}_{2}-4 \mathrm{~b},-8 \mathrm{a},-13 \mathrm{a},-17 \mathrm{a},-20 \mathrm{~b}\right), 2.11(8 \mathrm{H}$, $\left.\mathrm{m}, \mathrm{H}_{2}-8 \mathrm{~b},-9,12 \mathrm{a},-13 \mathrm{~b},-16,-17 \mathrm{~b}\right), 1.77\left(2 \mathrm{H}, \mathrm{m}, \mathrm{H}_{2}-21\right), 1.67\left(3 \mathrm{H}, \mathrm{s}, \mathrm{H}_{3}-26\right), 1.62,\left(3 \mathrm{H}, \mathrm{s}, \mathrm{H}_{3}-27,-28\right), 1.60$ $\left(3 \mathrm{H}, \mathrm{s}, \mathrm{H}_{3}-29\right), 1.56\left(3 \mathrm{H}, \mathrm{s}, \mathrm{H}_{3}-1\right), 1.51\left(3 \mathrm{H}, \mathrm{s}, \mathrm{H}_{3}-24\right), 1.45\left(3 \mathrm{H}, \mathrm{s}, \mathrm{H}_{3}-25\right), 1.44\left(3 \mathrm{H}, \mathrm{s}, \mathrm{H}_{3}-30\right)$.

3,22-Bis-MTPA Ester of 3 (3a). ${ }^{1} \mathrm{H}-\mathrm{NMR}$ (pyridine- $\left.d_{5}, 600 \mathrm{MHz}\right) \delta_{\mathrm{H}} 5.90(1 \mathrm{H}, \mathrm{m}, \mathrm{H}-7), 5.87(1 \mathrm{H}, \mathrm{m}, \mathrm{H}-8)$, $5.70(1 \mathrm{H}, \mathrm{m}, \mathrm{H}-18), 5.52(1 \mathrm{H}, \mathrm{m}, \mathrm{H}-14), 5.45(2 \mathrm{H}, \mathrm{m}, \mathrm{H}-3,-22), 5.38(1 \mathrm{H}, \mathrm{m}, \mathrm{H}-10), 2.90\left(2 \mathrm{H}, \mathrm{m}, \mathrm{H}_{2}-9\right)$, $2.56\left(1 \mathrm{H}, \mathrm{m}, \mathrm{H}_{2}-20 \mathrm{a}\right), 2.01\left(1 \mathrm{H}, \mathrm{m}, \mathrm{H}_{2}-4 \mathrm{a}\right), 1.96\left(13 \mathrm{H}, \mathrm{m}, \mathrm{H}_{2}-8,-9,-12,-13,-16,-17,-20 \mathrm{~b}\right), 1.88(2 \mathrm{H}, \mathrm{m}$, $\left.\mathrm{H}_{2}-21\right), 1.83\left(2 \mathrm{H}, \mathrm{m}, \mathrm{H}_{2}-5\right), 1.70\left(3 \mathrm{H}, \mathrm{s}, \mathrm{H}_{3}-28\right), 1.66,\left(3 \mathrm{H}, \mathrm{s}, \mathrm{H}_{3}-29\right), 1.62,\left(3 \mathrm{H}, \mathrm{s}, \mathrm{H}_{3}-27\right), 1.54(3 \mathrm{H}, \mathrm{s}$, $\left.\mathrm{H}_{3}-1\right), 1.53\left(3 \mathrm{H}, \mathrm{s}, \mathrm{H}_{3}-30\right), 1.52\left(3 \mathrm{H}, \mathrm{s}, \mathrm{H}_{3}-26\right), 1.51\left(3 \mathrm{H}, \mathrm{s}, \mathrm{H}_{3}-24\right), 1.50\left(3 \mathrm{H}, \mathrm{s}, \mathrm{H}_{3}-25\right)$.

3,22-Bis-MTPA Ester of $3(3 \mathbf{b}) .{ }^{1} \mathrm{H}-\mathrm{NMR}$ (pyridine- $\left.d_{5}, 600 \mathrm{MHz}\right) \delta_{\mathrm{H}} 5.89(1 \mathrm{H}, \mathrm{m}, \mathrm{H}-7), 5.86(1 \mathrm{H}, \mathrm{m}, \mathrm{H}-8)$, $5.72(1 \mathrm{H}, \mathrm{m}, \mathrm{H}-18), 5.53(1 \mathrm{H}, \mathrm{m}, \mathrm{H}-14), 5.44(2 \mathrm{H}, \mathrm{m}, \mathrm{H}-3,-22), 5.38(1 \mathrm{H}, \mathrm{m}, \mathrm{H}-10), 2.90\left(2 \mathrm{H}, \mathrm{m}, \mathrm{H}_{2}-9\right)$, $2.55\left(1 \mathrm{H}, \mathrm{m}, \mathrm{H}_{2}-20 \mathrm{a}\right), 2.08\left(1 \mathrm{H}, \mathrm{m}, \mathrm{H}_{2}-4 \mathrm{a}\right), 1.91\left(13 \mathrm{H}, \mathrm{m}, \mathrm{H}_{2}-8,-9,-12,-13,-16,-17,-20 \mathrm{~b}\right), 1.80(2 \mathrm{H}, \mathrm{m}$, $\left.\mathrm{H}_{2}-21\right), 1.79\left(2 \mathrm{H}, \mathrm{m}, \mathrm{H}_{2}-5\right), 1.70\left(3 \mathrm{H}, \mathrm{s}, \mathrm{H}_{3}-28\right), 1.66$, $\left(3 \mathrm{H}, \mathrm{s}, \mathrm{H}_{3}-29\right), 1.62,\left(3 \mathrm{H}, \mathrm{s}, \mathrm{H}_{3}-27\right), 1.53\left(3 \mathrm{H}, \mathrm{s}_{3} \mathrm{H}_{3}-1\right.$, $-30), 1.52\left(3 \mathrm{H}, \mathrm{s}, \mathrm{H}_{3}-26\right), 1.51\left(3 \mathrm{H}, \mathrm{s}, \mathrm{H}_{3}-24\right), 1.50\left(3 \mathrm{H}, \mathrm{s}, \mathrm{H}_{3}-25\right)$.

\subsection{Biological Materials and Cell Culture}

Recombinant human IL-6 was purchased from R\&D Systems (Minneapolis, MN, USA). Mouse anti-phospho Stat3 $\left(\mathrm{Tyr}^{705}\right)$ IgG was purchased from Calbiochem (Darmstadt, Germany). All reagents, including genistein, were obtained from Sigma-Aldrich Ltd. (St. Louis, MO, USA). Human hepatoma Hep3B and U266 cells were obtained from the American Type Culture Collection (ATCC No. HB-8064 and TIB-196TM, Rockville, MD, USA) and were maintained in DMEM and RPMI1640 media supplemented with $10 \%$ fetal bovine serum, $50 \mathrm{U} / \mathrm{mL}$ penicillin, and $50 \mathrm{mg} / \mathrm{mL}$ streptomycin at $37^{\circ} \mathrm{C}$ in a $5 \% \mathrm{CO}_{2}$ incubator. All cell culture reagents were obtained from GibcoBRL (Life Technologies, Cergy-Pontoise, France). 


\subsection{Luciferase Assay}

Hep3B cells stably expressing pStat3-Luc, which were previously established by Chang et al. [32], were seeded onto 96-well culture plates at $2 \times 10^{4}$ cells/well. After $24 \mathrm{~h}$, the cells were starved for $12 \mathrm{~h}$ and were then treated with IL-6 $(10 \mathrm{ng} / \mathrm{mL})$ with or without compounds for $12 \mathrm{~h}$. The luciferase assay was performed with a Promega kit according to the manufacturer's protocol (Madison, WI, USA).

\subsection{Cell Viability}

Hep3B cells were seeded at a plating density of $2 \times 10^{4}$ cells/well and were cultured for $24 \mathrm{~h}$ to allow them to adhere to the plate. After $24 \mathrm{~h}$, the culture medium was changed to serum-free medium supplemented with samples at the indicated dose. MTT $(0.5 \mathrm{mg} / \mathrm{mL})$ was added after a $48 \mathrm{~h}$ culture, and $200 \mu \mathrm{L}$ of DMSO was then added to each well after a $4 \mathrm{~h}$ incubation at $37^{\circ} \mathrm{C}$. The absorbance of the samples at $540 \mathrm{~nm}$ was measured against a background control using a 96-well plate reader. The percentage of viable cells under each treatment condition was determined relative to the negative control.

\subsection{Western Blotting Analysis}

U266 cells were stimulated with IL-6 $(10 \mathrm{ng} / \mathrm{mL})$ for $20 \mathrm{~min}$ in the presence or absence of compounds. Western blot analysis was performed to evaluate STAT3 and JAK2 protein expression in the U266 cell line, as described in previous studies [33]. The phosphorylation status of STAT3 and JAK2 was examined using anti-phospho-Stat3 (1:1000), anti-Stat3 (1:1000), anti-phospho-Jak2 (1:1000), and anti-Jak2 (1:1000) antibodies (Cell Signaling, Beverly, MA, USA) and then were incubated with the appropriate horseradish peroxide-conjugated secondary antibody (1:5000) at RT. The optical densities of antibody-specific bands were quantified using ImageJ software.

\subsection{Statistical Analyses}

Data are expressed as the means \pm standard error of the mean (S.E.), and the statistical analyses were performed using Student's $t$-test in Prism 5 software (GraphPad software, San Diego, CA, USA). A probability value of $0.05(p<0.05)$ was considered significant.

\section{Conclusions}

In conclusion, four acyclic triterpenoid derivatives (1-4) were isolated from the $\mathrm{EtOH}$ extract of $A$. katsumadai. Compounds 3 and 4 were identified as new acyclic triterpenoids 2,3,6,22,23-pentahydroxy-2,6,11,15,19,23-hexamethyl-tetracosa-7,10,14,18-tetraene and 2,3,6,22,23-pentahydroxy-2,10,15,19,23-hexamethyl-7-methylenetetracosa-10,14,18-triene, respectively. In addition, major constituents, Compounds $\mathbf{1}$ and 2, in A. katsumadai showed more potent inhibitory activity on IL-6-induced STAT3 activation. Based on our results, these triterpenoids could be useful candidates for designing new IL-6 inhibitors as anti-inflammatory agents.

Supplementary Materials: Supplementary Materials are available online.

Acknowledgments: This research was supported by a National Research Foundation of Korea (NRF) (No. 2013003120) grant funded by the Korean government (MEST) and a KRIBB Research Initiative Program (KGM2221723).

Author Contributions: Hyun-Jae Jang and Seung Woong Lee conceived and designed the experiments; Seung-Jae Lee performed the Western blotting experiments; Soyoung Lee and Kyungsook Jung performed the IL-6/STAT3 assay; Seung Woong Lee analyzed the NMR data of the compounds; Mun-Chual Rho contributed reagents, materials, and analysis instruments; Hyun-Jae Jang and Seung Woong Lee wrote the manuscript.

Conflicts of Interest: The authors declare no conflicts of interest. 


\section{References}

1. Luger, T.A.; Schwarz, T.; Krutmann, J.; Kirnbauer, R.; Neuner, P.; Köck, A.; Urbanski, A.; Borth, W.; Schauer, E. Interleukin- 6 is produced by epidermal cells and plays an important role in the activation of human T-lymphocytes and natural killer cells. Ann. N. Y. Acad. Sci. 1989, 557, 405-414. [CrossRef] [PubMed]

2. Neveu, W.A.; Allard, J.B.; Dienz, O.; Wargo, M.J.; Ciliberto, G.; Whittaker, L.A.; Rincon, M. IL-6 is required for airway mucus production induced by inhaled fungal allergens. J. Immunol. 2009, 183, 1732-1738. [CrossRef] [PubMed]

3. Morishima, A.; Marui, A.; Shimamoto, T.; Saji, Y.; Nishina, T.; Komeda, M. A case of interleukin-6-producing cardiac myxoma resembling multicentric Castleman's disease. J. Thorac. Cardiovasc. Surg. 2009, 138, 499-501. [CrossRef] [PubMed]

4. Nishimoto, N.; Miyasaka, N.; Yamamoto, K.; Kawai, S.; Takeuchi, T.; Azuma, J. Long-term safety and efficacy of tocilizumab, an anti-IL-6 receptor monoclonal antibody, in monotherapy, in patients with rheumatoid arthritis (the STREAM study): Evidence of safety and efficacy in a 5-year extension study. Ann. Rheumatol. Dis. 2009, 68, 1580-1584. [CrossRef] [PubMed]

5. Bernberg, E.; Ulleryd, M.A.; Johansson, M.E.; Bergström, G.M. Social disruption stress increases IL-6 levels and accelerates atherosclerosis in ApoE-/- mice. Atherosclerosis 2012, 221, 359-365. [CrossRef] [PubMed]

6. Kristiansen, O.P.; Mandrup-Poulsen, T. Interleukin-6 and Diabetes. Diabetes 2005, 54, 114-124. [CrossRef]

7. Fulciniti, M.; Hideshima, T.; Vermot-Desroches, C.; Pozzi, S.; Nanjappa, P.; Shen, Z.; Patel, N.; Smith, E.S.; Wang, W.; Prabhala, R.; et al. A high-affinity fully human anti-IL-6 mAb, 1339, for the treatment of multiple myeloma. Clin. Cancer Res. 2009, 15, 7144-7152. [CrossRef] [PubMed]

8. Bhagat, K.; Vallance, P. Inflammatory cytokines impair endothelium-dependent dilatation in human veins in vivo. Circulation 1997, 96, 3042-3407. [CrossRef] [PubMed]

9. Tang, W.; Eisenbrand, G. Chinese Drugs of Plant Origin; Springer: Berlin/Heidelberg, Germany, 1992; pp. 711-737.

10. Nam, J.W.; Kang, G.Y.; Han, A.R.; Lee, D.; Lee, Y.S.; Seo, E.K. Diarylheptanoids from the seeds of Alpinia katsumadai as heat shock factor 1 inducers. J. Nat. Prod. 2011, 74, 2109-2115. [CrossRef] [PubMed]

11. Yang, Y.; Koyama, K.; Takahashi, K.; Kondo, S.; Watanabe, K. Structure-antiemetic-activity of some diarylheptanoids and their analogues. Phytomedicine 2002, 9, 146-152. [CrossRef] [PubMed]

12. Yang, Y.; Koyama, K.; Takahashi, K.; Tai, T.; Nunoura, Y.; Watanabe, K. Two novel anti-emetic principles of Alpinia katsumadai. J. Nat. Prod. 1999, 62, 1672-1674. [CrossRef] [PubMed]

13. Ngo, K.S.; Brown, G.D. Stilbenes, monoterpenes, diarylheptanoids, labdanes and chalcones from Alpinia katsumadai. Phytochemistry 1998, 47, 1117-1123. [CrossRef]

14. Hua, S.Z.; Luo, J.G.; Wang, X.B.; Wang, J.S.; Kong, L.Y. Two novel monoterpene-chalcone conjugates isolated from the seeds of Alpinia katsumadai. Bioorg. Med. Chem. Lett. 2009, 19, 2728-2730. [CrossRef] [PubMed]

15. Hua, S.Z.; Wang, X.B.; Luo, J.G.; Wang, J.S.; Kong, L.Y. A pair of unique sesquiterpene-chalcone conjugates isolated from the seeds of Alpinia katsumadai. Tetrahedron Lett. 2008, 49, 5658-5661. [CrossRef]

16. Kuroyanagi, M.; Noro, T.; Fukushima, S.; Aiyama, R.; Ikuta, A.; Itokawa, H.; Morita, M. Studies on the constituents of the seeds of Alpinia katsumadai Hayata. Chem. Pharm. Bull. 1983, 31, 1544-1550. [CrossRef]

17. Du, J.; Tang, B.; Wang, J.; Sui, H.; Jin, X.; Wang, L.; Wang, Z. Antiproliferative effect of alpinetin in BxPC-3 pancreatic cancer cells. Int. J. Mol. Med. 2012, 29, 607-612. [CrossRef] [PubMed]

18. Kim, H.H.; Kwon, H.J.; Ryu, Y.B.; Chang, J.S.; Cho, K.O.; Hosmillo, M.D.; Rho, M.C.; Park, S.J.; Lee, W.S. Antiviral activity of Alpinia katsumadai extracts against rotaviruses. Res. Vet. Sci. 2012, 92, 320-323. [CrossRef] [PubMed]

19. Kwon, H.J.; Kim, H.H.; Yoon, S.Y.; Ryu, Y.B.; Chang, J.S.; Cho, K.O.; Rho, M.C.; Park, S.J.; Lee, W.S. In vitro inhibitory activity of Alpinia katsumadai extracts against influenza virus infection and hemagglutination. Virol. J. 2010, 7, 307. [CrossRef] [PubMed]

20. Lee, M.Y.; Lee, N.H.; Seo, C.S.; Lee, J.A.; Jung, D.; Kim, J.H.; Shin, H.K. Alpinia katsumadai seed extract attenuate oxidative stress and asthmatic activity in a mouse model of allergic asthma. Food Chem. Toxicol. 2010, 48, 1746-1752. [CrossRef] [PubMed]

21. Yang, J.; Dai, Y.; Xia, Y.F.; Huang, W.Z.; Wang, Z.T. Alpinia katsumadai hayata prevents mouse sepsis induced by cecal ligation and puncture through promoting bacterial clearance and downregulating systemic inflammation. Phytother. Res. 2009, 23, 267-273. [CrossRef] [PubMed] 
22. Jeong, G.S.; Li, B.; Lee, D.S.; Byun, E.; Kang, D.G.; Lee, H.S.; Kim, Y.C. Cytoprotective constituents of Alpinia katsumadai seeds against glutamate-induced oxidative injury in HT22 cells. Nat. Prod. Sci. 2007, 13, $268-271$.

23. Nishiyama, Y.; Moriyasu, M.; Ichimaru, M.; Tachibana, Y.; Kato, A.; Mathenge, S.G.; Nganga, J.N.; Juma, F.D. Acyclic triterpenoids from Ekebergia capensis. Phytochemistry 1996, 42, 803-807. [CrossRef]

24. Nishiyama, Y.; Moriyasu, M.; Ichimaru, M.; Kato, A.; Mathenge, S.G.; Naganga, J.N.; Juma, F.D. Absolute configurations of two acyclic triterpenoids from Ekebergia capensis. Phytochemistry 1999, 52, 1593-1596. [CrossRef]

25. Rho, M.C.; Kim, Y.K.; Lee, H.S.; Jun, C.D.; Kim, K.; Lee, S.W.; Choi, J.H.; Song, G.Y. New Acyclic Triterpenoids Compound, and Pharmaceutical Composition Comprising Alpinia katsumadai Extract or Acyclic Triterpenoids Compounds Isolated from the Same. World Patent WO2008133387, 6 November 2008.

26. Kouda, K.; Ooi, T.; Kusumi, T. Application of the modified Mosher's method to linear 1, 3-diols. Tetrahedron Lett. 1999, 40, 3005-3008. [CrossRef]

27. Kusumi, T.; Fukushima, T.; Ohtani, I.; Kakisawa, H. Elucidation of the absolute configurations of amino acids and amines by the modified Mosher's method. Tetrahedron Lett. 1991, 32, 2939-2942. [CrossRef]

28. Freire, F.; Seco, J.M.; Quiñoá, E.; Riguera, R. Determining the absolute stereochemistry of secondary/secondary diols by 1H-NMR: Basis and applications. J. Org. Chem. 2005, 70, 3778-3790. [CrossRef] [PubMed]

29. Lee, S.W.; Yun, B.R.; Kim, M.H.; Park, C.S.; Lee, W.S.; Oh, H.M.; Rho, M.C. Phenolic compounds isolated from Psoralea corylifolia inhibit IL-6-induced STAT3 activation. Planta Med. 2012, 78, 903-906. [CrossRef] [PubMed]

30. Hanada, T.; Yoshimura, A. Regulation of cytokine signaling and inflammation. Cytokine Growth Factor Rev. 2002, 13, 413-421. [CrossRef]

31. Kamimura, D.; Ishihara, K.; Hirano, T. IL-6 signal transduction and its physiological roles: The signal orchestration model. Rev. Physiol. Biochem. Pharmacol. 2003, 149, 1-38. [PubMed]

32. Chang, J.S.; Lee, S.W.; Kim, M.S.; Yun, B.R.; Park, M.H.; Lee, S.G.; Park, S.J.; Lee, W.S.; Rho, M.C. Manassantin A and B from Saururus chinensis inhibit interleukin-6-induced signal transducer and activator of transcription 3 activation in Hep3B Cells. J. Pharmacol. Sci. 2011, 115, 84-88. [CrossRef] [PubMed]

33. Lee, S.J.; Jang, H.J.; Kim, Y.; Oh, H.M.; Lee, S.; Jung, K.; Kim, Y.H.; Lee, W.S.; Lee, S.W.; Rho, M.C. Inhibitory effects of IL-6-induced STAT3 activation of bio-active compounds derived from Salvia plebeia R. Br. Process Biochem. 2016, 51, 2222-2229. [CrossRef]

Sample Availability: Compounds $\mathbf{1}$ and $\mathbf{2}$ are available from the authors.

(C) 2017 by the authors. Licensee MDPI, Basel, Switzerland. This article is an open access article distributed under the terms and conditions of the Creative Commons Attribution (CC BY) license (http:/ / creativecommons.org/licenses/by/4.0/). 